\title{
БИОЛОГИЯ, ФЕНОТИПИЧЕСКАЯ И ГЕНОТИПИЧЕСКАЯ СТРУКТУРА ПОПУЛЯЦИЙ ХИЩНОГО КЛОПА Perillus bioculatus Fabr. (Heteroptera, Pentatomidae) В КРАСНОДАРСКОМ КРАЕ
}

\author{
В.Я. ИСМАИЛОВ1, И.С. АГАСЬЕВАํㅛ, В.И. КИЛЬ², Е.В. ФЕДОРЕНКО1, \\ М.В. НЕФЕДОВА ${ }^{1}$, Е.Н. БЕСЕДИНА ${ }^{1}$
}

\begin{abstract}
Хищный клоп Perillus bioculatus Fabr. (1775) - представитель семейства Pentatomidae. Наиболее предпочтительным пищевым объектом этого хищника считались яйцекладки колорадского жука, и это ограничение рассматривалось как главное препятствие для акклиматизации периллюса на новых территориях. Наше исследование показало, что акклиматизировавшийся запоследние 10 лет на юге России хищник питается не только всеми наземными стадиями колорадского жука, но и личинками, жуками амброзиевого листоеда Zygogramma suturalis Fabr., гусеницами амброзиевой совки Tarachidia candefacta Hübn. (Noctuidae: Lepidoptera) и другими видами насекомых. В условиях Краснодарского края периллюс развивается в трех генерациях и представлен тремя феноформами - с красно-черной, оранжево-черной и бело-черной окраской щитка. На численность $P$. bioculatus в основном влияет наличие достаточной кормовой базы, также размер популяции хищника ограничивают энтомофаги - паразиты-яйцееды рода Trissolcus (Hymenoptera: Scelionidae) и мухи-фазии (Diptera: Tachinidae). Мы провели генетический анализ признака «окраска щитка» у имаго клопа периллюса, использовав семь комбинаций скрещиваний (в том числе выполнив реципрокные скрещивания) между красными, оранжевыми (или желтыми) и белыми родительскими формами. Установлено, что во всех комбинациях, включая скрещивание белых особей с белыми, насекомые в потомстве имели только красные и оранжевые щитки в соотношении 1:1 (как в $\mathrm{F}_{1}$, так и в $\mathrm{F}_{2}$ ). PCR-анализ ДНК клопов P. bioculatus в потомстве $\mathrm{F}_{2}$ от скрещивания насекомых разных феноформ выявил неодинаковую частоту некоторых RAPD (random amplification of polymorphic DNA)-маркеров у клопов одинаковых феноформ в $F_{2}$, то есть их генетические различия. Полученные данные свидетельствуют о неменделевском характере наследования признака «окраска щитка» у клопа периллюса, что дополнительно вызывает интерес к более детальному генетическому анализу этого признака и его изменчивости в зависимости от условий внешней среды. На основании результатов RAPD- и ISSR (inter simple sequence repeat)-PCR анализа мы оценили изменчивость молекулярно-генетической структуры географических популяций периллюса из разных зон Краснодарского края. Статистически значимые различия $(\mathbf{p}=0,05)$ выявлены между популяциями почти со всеми праймерами. Старо-Нижестеблиевская популяция оказалась близка по структуре к краснодарской, тогда как ее генетическое сходство с популяцией из села Молдовановское было низким, что согласуется с их географическим положением и свидетельствует о наличии географической изменчивости генетической структуры P. bioculatus. Выполненные нами исследования подтверждают пластичность вида, что дает основание для продолжения его акклиматизации на территориях современного ареала колорадского жука.
\end{abstract}

Ключевые слова: хищные клопы, Perillus bioculatus Fabr., адвентивный вид, натурализация, PCR-анализ, генетическое сходство, колорадский жук, энтомофаги, биоконтроль.

В Европе и Азии колорадский жук (Leptinotarsa decemlineata Say) aкклиматизировался от южных районов Дании до Испании и Португалии, от северо-запада европейской территории России до Сибири и Дальнего Востока (1-4). Рост популяции колорадского жука при отсутствии постоянных обработок пестицидами могут ограничивать неблагоприятные погодные условия, нехватка корма или энтомофаги и энтомопатогены. Однако до недавнего времени в пределах европейского ареала этого вредителя отсутствовали специализированные энтомофаги, которые могли бы снижать его численность. Несмотря на успешное применение естественных врагов против многих видов клещей и вредных насекомых, подобные приемы против колорадского жука либо отсутствуют, либо ограничены небольшими площадями, хотя известны его эффективные естественные враги (5).

Систематически применяемые обработки инсектицидами обеспе-

* Исследования выполнены согласно Государственному заданию № 075-00376-19-00 Министерства науки и высшего образования РФ в рамках НИР по теме № 0686-2019-0009.

110 
чивают сохранение урожая сельскохозяйственных культур (6), но приводят к очень большим и во многих случаях излишним затратам из-за отсутствия учета полезной деятельности естественных врагов вредителей (7-10).

Возможность использовать биологические средства против колорадского жука привлекла внимание ученых после того, как вредитель широко распространился в США, Канаде, а затем и в Европе (11). Предметом этих исследований были патогенные микроорганизмы как основа микробиологических препаратов, местная энтомофауна (для выявления эффективных естественных врагов L. decemlineata), велись работы по интродуции энтомофагов колорадского жука из Северной Америки $(5,12,13)$.

Исследования по акклиматизации североамериканского хищного клопа Perillus bioculatus Fabr. начались во Франции в 1930-е годы и активно возобновились в 1950-1960-е годы (14). На территории Европы интродуцировали представителей подсемейства Asopinae - периллюса Perillus bioculatus, подизуса Podisus maculiventris Say, опломуса Oplomus nigripennis var. pulcher Dull., а также паразитических мух из рода Doryphorophaga (15-17). Начиная с 1966 года, периллюса завозили в Бельгию, Францию, Германию, Италию, СССР, Словакию, Югославия, на Украину с целью естественного регулирования численности L. decemlineata $(18,19)$, который быстро стал нечувствительным к используемым инсектицидам (20-23), при этом проявляя перекрестную устойчивость (24-27). Для акклиматизации энтомофага была создана интернациональная рабочая группа энтомологов из ФРГ, Бельгии, Чехословакии, Венгрии, Болгарии, Польши, которые осуществляли разведение и выпуск периллюса в агроценозы (14).

В СССР работы по интродукции этого хищного клопа (как предполагаемого наиболее перспективного биоагента для контроля колорадского жука) проводились в 1960-1970 годы, но добиться его акклиматизации и/или использовать сезонную колонизацию не удалось. В последние 25-30 лет об исследованиях периллюса в России практически не сообщалось. В 2008 году в г. Краснодаре была обнаружена естественно акклиматизировавшаяся популяция периллюса $(28,29)$. Для выявления причин его натурализации и адаптации, определения ареала и оценки перспектив практического применения в защите против колорадского жука велись наблюдения за биологическими особенностями хищника и мониторинг морфогенетической структуры его краснодарской популяции $(30,31)$. В последние годы в Усть-Лабинском и Абинском районах Краснодарского края также выявлены географические популяции P. bioculatus Fabr. Paнеe периллюса обнаружили в нескольких районах Кубани, Адыгеи, в Ростовской области, на Украине, в Молдавии, Турции и других странах, что дает основание для предположения о его масштабной акклиматизации в странах Старого Света (32).

Настоящая работа суммирует данные по биологии и филогении естественно акклиматизировавшегося в Краснодарском крае хищного клопа периллюса. Нами впервые выявлена географическая изменчивость генетической структуры и разнообразия краснодарской популяции этого нового для Европы вида и описаны биотические факторы, влияющие на динамику его численности.

Нашей целью было изучение биологических особенностей и фенетической структуры популяций периллюса по окраске щитка, включая анализ характера наследования этого признака с оценкой генетического сходства популяций P. bioculatus.

Meтодика. Исследовали выборки P. bioculatus из различных географических популяций (Краснодарский край, Ростовская область, Респуб- 
лики Адыгея), собранные в 2014-2015 годах. Наблюдения проводили в условиях стационарного севооборота (Всероссийский НИИ биологической защиты растений - ВНИИБЗР) и в хозяйствах Краснодарского края, использующих систему органического земледелия (2014-2016 годы). Учитывали яйца, личинок и имаго колорадского жука в расчете на 1 куст (картофель сортов Голландка, Удача, Луговской), численность амброзиевого листоеда Zygogramma suturalis Fabr. в расчете на 1 м $^{2}$ площади (растения, поверхность почвы и ее слой 0-12 см), а также личинок и имаго периллюса (33).

В лабораторных условиях периллюса выращивали на яйцекладках и личинках L. decemlineata, а также на гусеницах вощинной моли (Galleria mellonella L.) 2-го и 3-го возрастов. Оптимальные для развития периллюса условия - температура $24-25^{\circ} \mathrm{C}$, относительная влажность воздуха 70-80 \% и фотопериод 16 ч. Использовали разработанные нами ранее режимы хранения имаго клопов (29), для непрерывного поддержания лабораторной популяции применяли методы преодоления диапаузы (В.Я. Исмаилов и др., патент РФ № 2 14122878/10, 2015).

При гибридологическом анализе (реципрокные скрещивания) по одной паре половозрелых клопов разных феноформ в комбинациях оранже-

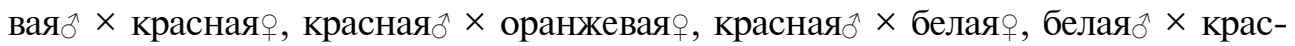

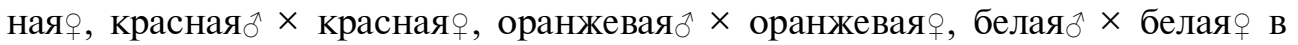
5 повторностях помещали в чашки Петри. Насекомых кормили яйцекладками и личинками колорадского жука, после выкормки 2-й и 3-й генераций хищника учитывали соотношение феноформ.

Для изучения генетического полиморфизма из каждой популяций отбирали по 20 особей. ДНК выделяли СТАВ-методом в нашей модификации (В.И. Киль. Методика оценки ДНК полиморфизма популяций насекомых с помощью RAPD- и ISSR-PCR). Методические рекомендации. Краснодар, 2009) с использованием соответствющих реактивов («ДиаЭм», Россия). Чистоту (по $\mathrm{OD}_{260} / \mathrm{OD}_{280}$ ) и концентрацию препаратов определяли спектрофотометрически (Hitachi Perkin Elmer 124, «Hitachi, Ltd», Япония).

ДНК полиморфизм оценивали методом RAPD (random amplification of polymorphic DNA)- и ISSR (inter simple sequence repeat)-PCR (В.И. Киль. Методика оценки ДНК полиморфизма популяций насекомых с помощью RAPD- и ISSR-PCR). Методические рекомендации. Краснодар, 2009) (амплификатор iCycler, «Bio-Rad Laboratories, Inc.», США) с электрофоретическим разделением ампликонов (прибор Sub Cell-GT с источником питания Power Pac-Basic, «Bio-Rad Laboratories, Inc.», США; реактивы фирм ООО «ДиаЭм», Россия; «Диалат Лтд.», Россия). Использовали ДНК-полимеразу (5 IU/мкл, «Диалат Лтд.», Россия), маркер молекулярных масс (М 100bp, ООО «СибЭнзим», Россия) и стандартные праймеры, разработанные в «Operon Technology, Inc.» (США) (OP) и University of British Columbia (Канада) (UBC), - UBC880 (ISSR) и OPA02, OPA07, OPA20, OPB01, OPE07, UBC450, UBC531 (RAPD) (синтезированы ООО «СибЭнзим», Россия). Амплифицированные фрагменты разделяли в 1,8\% агарозе («AppliChem GmbH», Германия). Фотодокументирование выполняли на трансиллюминаторе ECX-20-M («Vilber Lourmat», Франция). Сравниваемые образцы ДНК амплифицировали в одной PCR в 2 аналитических повторностях.

Частоту встречаемости ДНК маркеров и ее изменчивость оценивали по $\chi^{2}$-критерию, достоверность различий между средними по выборке на основании $t$-критерия Стьюдента. Оценку статистических различий проводили при $5 \%$ уровне значимости. Показатели полиморфизма вычисляли как процентное отношение числа полиморфных фрагментов к общему чис- 
лу ДНК маркеров. Генетическое разнообразие популяций и генетических расстояний оценивали по М. Nei и C. Schennon, используя пакет программ POPGENE v1.31 (https://sites.ualberta.ca/ fyeh/index.html) (34).

Результаты. Мы изучили обнаруженные популяций периллюса как в полевых условиях, так и лабораторными методами. Для этого были оптимизированы режимы сохранения имаго клопов (до 10-15 сут при 4 $\mathrm{C}$ ) (29). Лабораторная популяция P. bioculatus поддерживалась непрерывно благодаря разработанной нами методике преодоления диапаузы посредством 10-15суточного содержания насекомых при низких температурах (3-4 $\left.{ }^{\circ} \mathrm{C}\right)$ с последующим лабораторным разведением в оптимальных условиях (В.Я. Исмаилов и др., патент РФ № 2 14122878/10, 2015).

Биологические особенности и фенетическая структура популяций периллюса. Наблюдения за популяциями P. bioculatus и его жертв проводили на основе регулярных ежегодных и сезонных наблюдений. В 2015 году перезимовавшие жуки L. decemlineata появились в III декаде апреля, первые яйцекладки - 1-3 мая. В I декаде мая на опытном участке на растениях картофеля отмечали первых особей P. bioculatus, во II декаде мая численность клопа начала постепенно нарастать. В начале вегетации периллюс был представлен красной феноформой, в III декаде мая появились особи белой феноформы, и только в III декаде августа небольшое количество клопов с оранжевой окраской щитка. В этой популяции 80,0 \% (603 эк3.) составляли особи с красно-черным, 17,0 \% (128 экз.) - с оранжево-черным и 3,0 \% (23 экз.) - с черно-белым рисунком щитка (объем выборки - 754 насекомых). В 2012 году доли этих феноформ составляли соответственно 71,3 \% (445 эК3.), 17,9\% (111 эК3.) и $10,8 \%$ (69 экз.), в 2013 году - 74,9 \% (540 экз.), 20,1 \% (144 экз.) и 5,0 \% (37 экз.), в 2014 году - 70,0 \% (480 экз.), 15\% (103 экз.) и $15 \%$ (103 экз.). Мы сравнили долю особей $P$. bioculatus с разной окраской щитка по годам, использовав $\chi^{2}$-критерия в форме, позволяющей оценить сходство двух или более эмпирических распределений (35). В результате получили величину $\chi^{2}=11,7$, которая меньше стандартной для уровня статистической значимости $5 \%\left(\chi^{2}\right.$ ст. $\left.[\mathrm{df}=11]=19,7\right)$. Иными словами, соотношение особей с неодинаковой окраской не зависит от года исследования (различия по годам статистически недостоверны).

В настоящее время в природных условиях Краснодарского края и Республики Молдова $(36,37)$ встречаются красные, белые, а также оранжевые особи. В исследованиях, проведенных Е.М. Шаговым (г. Мукачево, Закарпатская обл., 1968 год), описываются насекомые, имеющие желтую (оранжевую) и белую окраску щитка (38). Е.М. Шагов отмечал, что чем выше температура, тем светлее окраска щитка у P. bioculatus (38). Наши наблюдения за периллюсом в природных условиях Краснодарского края подтверждают эту зависимость. В начале мая 2014 года периллюс был представлен красной морфой (среднедекадная температура в этот период составляла около $20{ }^{\circ} \mathrm{C}$ ), к середине мая отмечали оранжевых особей (около $23^{\circ} \mathrm{C}$ ) и только к середине июля (около $24,5^{\circ} \mathrm{C}$ ) появилась белая морфа насекомых. Полученные нами данные согласуются с сообщением о расщеплении фермента, влияющего на формирование окраски щитка периллюса, при повышенных температурах (39). Однако в условиях лабораторного выращивания такой зависимости мы не наблюдали. Насекомые, содержащиеся в климатической камере в одинаковых условиях (камера поддерживает режим «день-ночь») также имели различную окраску щитка (в основном красную, реже оранжевую); при этом белая окраска встречалась крайне редко. 
Мы установили, что в Центральной зоне Краснодарского края $P$. bioculatus развивается в трех генерациях и его численность в течение всего периода вегетации составляет от 2 до 15 экз/м² картофельного поля, что достаточно для подавления популяции колорадского жука и отмены химических обработок.

Наши наблюдения показали, что у акклиматизировавшейся в Краснодарском крае популяция $P$. bioculatus по сравнению с интродуцированной в 1960-1970 годы расширились трофические связи с колорадским жуком: исходно периллюсы питались только яйцами этого фитофага $(14,40)$, тогда как у натурализовавшейся популяция кормовую базу составляли все открыто живущие стадии развития L. decemlineata (яйца, личинки всех возрастов и имаго). Такое пищевое поведение хищника позволили преодолеть асинхронность развития P. bioculatus и L. decemlineata во II и III декадах апреля и в I декаде мая, что повышает выживаемость хищника и его биорегуляторную активность.

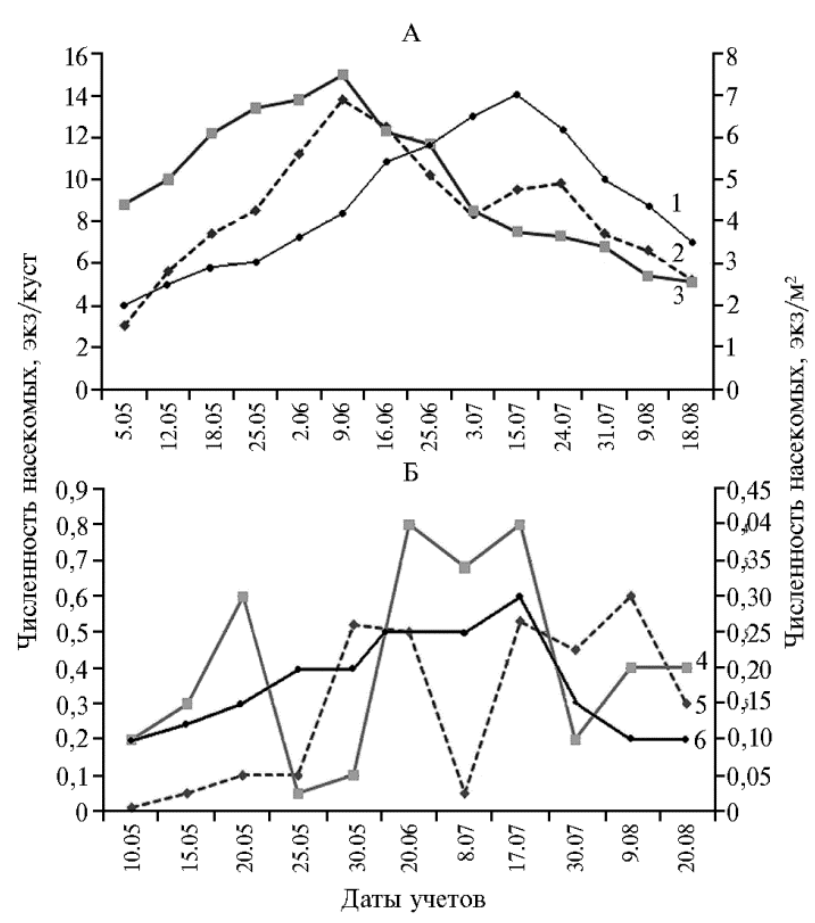

Рис. 1. Динамика численности имаго Leptinotarsa decemlineata Say, Zygogramma suturalis Fabr. и Perillus bioculatus Fabr. в период вегетации в 2014 (А) и 2015 году (Б): 1 - Z. suturalis, $2-$ L. decemlineata, $3-P$. bioculatus, $4-$ L. decemlineata, $5-$ P. bioculatus, 6 - Z. suturalis (стационарный севооборот ВНИИБЗР, г. Краснодар).

Для оценки влияния биотических факторов на динамику развития природных популяций P. bioculatus мы провели наблюдения за хищником на разных стадиях его развития в естественных стациях. В первую очередь изучали кормовую базу периллюса, одновременно учитывая численность хищного клопа и его жертв - колорадского жука L. decemlineata и амброзиевого листоеда Z. suturalis (рис. 1). На основании проведенных исследований была установлена определяющая роль кормовой базы в динамике численности хищного клопа периллюса. Например, сокращение популяций амброзиевого листоеда и колорадского жука в учетных стациях (опытные поля ВНИИБЗР) стало определяющим фактором при значи- 
тельном уменьшении плотности популяции хищника, которая достигала

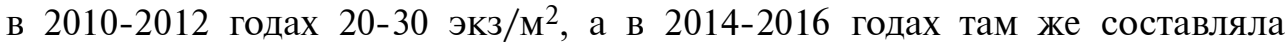
только 2-3 экз/м². В это же время (в 2014-2016 годах) в юго-восточных районах Республики Адыгея, где плотность популяций амброзиевого и картофельного листоедов была высокой, численность энтомофага также оставалась высокой (до 10-15 экз/м²).

Еще один не менее важный биотический фактор - активность других энтомофагов. В некоторые годы отмечалась значительная зараженность яйцекладок периллюса паразитом-яйцеедом Trissolcus vassillievi (Mayr) (Hymenoptera: Scelionidae) - от 5 до $28 \%$. Мухи-фазии (подсем. Phasiinae, сем. Tachinidae) заражали 3-15\%, а эктопаразитические клещи до $10 \%$ имаго хищника.

Периллюс в качестве корма предпочитал яйца колорадского жука, но не менее активно поедал личинок всех возрастов и взрослых жуков. В естесвтенных условиях, кроме колорадского жука, хищник питался личинками и имаго амброзиевого листоеда и гусеницами амброзиевой совки Tarachidia candefacta Hübn.

Характер наследования окраски щитка у клопа периллюса. В семи различных комбинациях скрещиваний (в том числе в реципрокных) между красными, оранжевыми (или желтыми) и белыми родительскими формами в потомстве (как в $\mathrm{F}_{1}$, так и в $\mathrm{F}_{2}$ ), в том числе при скрещивании белых особей с белыми, получили только особей с красным и оранжевым щитком в соотношении 1:1. В отличие от природной, лабораторная популяция не содержала белых феноформ. Отсутствие единообразия в $F_{1}$, отсутствие в потомстве белых феноформ и равное соотношение красных и оранжевых морфотипов в $\mathrm{F}_{2}$ свидетельствуют о неменделевском характере наследования признака и его обусловленности (наряду с генетической компонентой) условиями содержания насекомых (температура, продолжительность фотопериода и т.д.).

Сравнительный анализ географических популяций периллюса по ДНК маркерам. В 2015 году были обнаружены новые географические популяции периллюса в станице Варениковской (Краснодарский край, Крымский р-н), в поселке Шунтук (Майкопская станция Всероссийского НИИ генетических ресурсов растений им. Н.И. Вавилова, Республика Адыгея) и Аксайском районе Ростовской области. На основе их сравнения по выживаемости в зависимости от вида корма была отобрана популяция, наиболее подходящая для лабораторного разведения. По биологическим показателям популяция периллюсов, собранных на растениях картофеля в селе Молдаванское, значительно отличалась от краснодарской.

В результате наиболее приспособленными для лабораторного культивирования оказались стартовые популяции из станицы Варениковская и г. Краснодара. При питании вощинной молью (Galleria mellonella L.) число отложенных яиц на одну самку у них составило 70,4-81,6 шт., а популяция из села Молдавановское оказалась непригодной для лабораторного разведения хищника. Окрылившихся клопов в этой популяции при кормлении личинок колорадским жуком оказалось всего 21,3\%, а при переводе на питание дополнительной жертвой - вощинной молью выживаемость молдавановской популяции периллюса резко упала, что привело к потере маточной лабораторной популяции, в то время как краснодарская продолжала успешно развиваться и размножаться.

Выявленные особенности (наряду с различиями в фенотипической структуре) позволили сделать вывод о генотипических различиях популяций периллюса из окрестностей г. Краснодара и из Крымского района. 
Это подтвердил PCR-анализ ДНК клопов P. bioculatus, выполненный с двумя (OPA02, OPA20) RAPD- и одним (UBC880) ISSR-праймерами. Было обнаружено отсутствие различий по ДНК полиморфизму между краснодарской и старо-нижестеблиевской (Крымский р-н, Краснодарсий край) популяциями насекомых (выборка 2014 года) (табл. 1).

1. ДНК полиморфизм и генетическая структура географических популяций Perillus bioculatus Fabr. (Краснодарский край, 2014 год)

\begin{tabular}{|c|c|c|c|c|c|c|}
\hline \multirow[t]{2}{*}{ Праймер } & \multicolumn{2}{|c|}{$\begin{array}{l}\text { ДНК поли- } \\
\text { морфизм, \% }\end{array}$} & \multicolumn{2}{|c|}{$\begin{array}{l}\text { Число ДНК-фрагментов } \\
\text { на особь, } M \pm \text { SEM }\end{array}$} & \multirow{2}{*}{$\begin{array}{l}\text { Число детекти- } \\
\text { руемых ДНК- } \\
\text { маркеров, } n\end{array}$} & \multirow{2}{*}{$\begin{array}{l}\text { Различия между выбор- } \\
\text { ками по частоте ДНК } \\
\text { маркеров, } \chi^{2}\end{array}$} \\
\hline & $\mathrm{CH}$ & $\mathrm{K}$ & $\mathrm{CH}$ & $\mathrm{K}$ & & \\
\hline$\overline{\text { OPA02 }}$ & 100 & 100 & $7,9 \pm 1,4$ & $8,2 \pm 0,7$ & 26 & 25,6 \\
\hline OPA20 & 100 & 100 & $4,0 \pm 1,3$ & $5,0 \pm 0,8$ & 22 & 18,5 \\
\hline UBC 880 & 100 & 100 & $4,0 \pm 0,7$ & $2,0 \pm 0,2^{*}$ & 11 & 14,9 \\
\hline
\end{tabular}

2. Генетическое разнообразие географических популяций Perillus bioculatus Fabr. в разные годы (Краснодарский край)

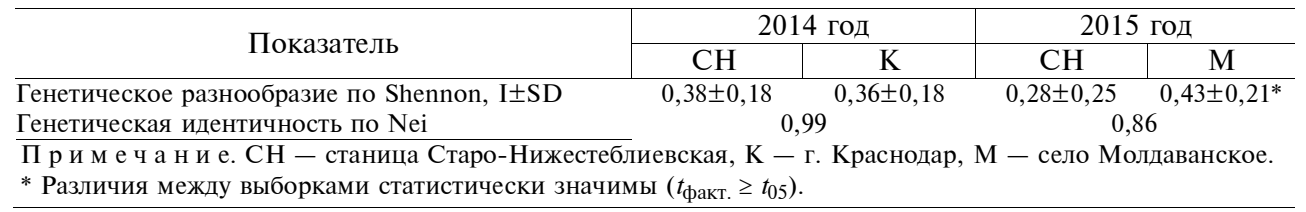
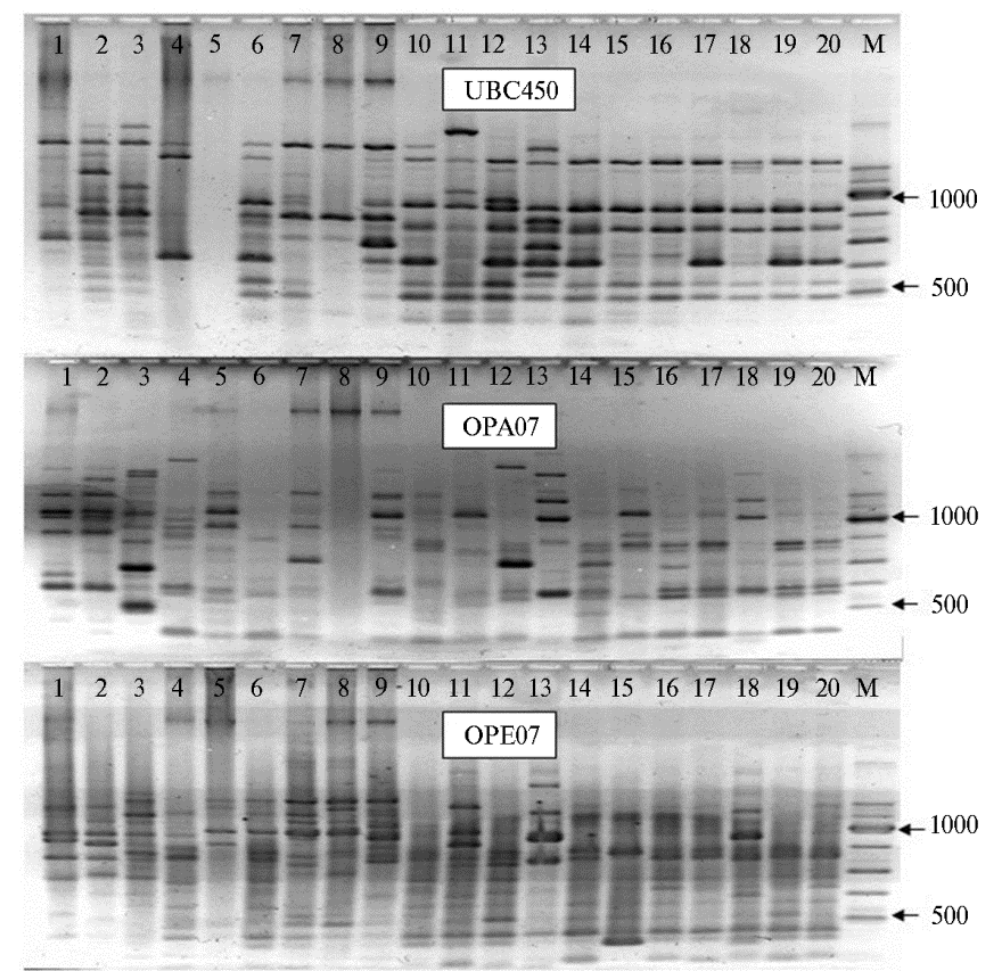

Рис. 2. RAPD-PCR-анализ ДНК Perillus bioculatus Fabr. из разных географических популяций (Краснодарский край, 2015 год): 1-10 - станица Старо-Нижестеблиевской; 11-20 - село Молдавановское; UBC450, ОРА07, ОРЕ07 - использованные праймеры; М - маркер молекулярных масс (М 100bp, «СибЭнзим», Россия). Разделение в 1,8 \% агарозе.

Между исследованными выборками имелось высокое генетическое сходство - 0,99 (табл. 2). Внутрипопуляционное генетическое разнообразие у исследованных географических выборок (краснодарской и старо- 
нижестеблиевской) не различалось (см. табл. 2). Полученные данные указывают на высокую миграционную способность вида и на то, что исследуемые выборки принадлежат, вероятно, к одной географической популяции.

В 2015 году для получения более развернутой информации по полиморфизму периллюса мы использовали дополнительные праймеры OPA07, OPB01, OPE07 и UBC450. PCR-анализ выборок (станица СтароНижестеблиевская и село Молдаванское, 2015 год) выявил статистически значимые различия по генетической структуре и ДНК полиморфизму практически со всеми использованными праймерам (рис. 2, табл. 3). Показатели генетического разнообразии этих выборок различались, а их генетическое сходство было относительно низким $(0,86)$ (см. табл. 2).

3. ДНК полиморфизм и генетическая структура географических популяций Perillus bioculatus Fabr. (Краснодарский край, 2015 год)

\begin{tabular}{|c|c|c|c|c|c|c|}
\hline \multirow[t]{2}{*}{ Праймер } & \multicolumn{2}{|c|}{$\begin{array}{l}\text { ДНК поли- } \\
\text { морфизм, \% }\end{array}$} & \multicolumn{2}{|c|}{$\begin{array}{l}\text { Число ДНК фрагментов } \\
\text { на особь, } M \pm \text { SEM }\end{array}$} & \multirow{2}{*}{\begin{tabular}{|l|} 
Число детекти- \\
руемых ДНК \\
маркеров, $n$
\end{tabular}} & \multirow{2}{*}{$\begin{array}{l}\text { Различия между вы- } \\
\text { борками по частоте } \\
\text { ДНК маркеров, } \chi^{2}\end{array}$} \\
\hline & $\mathrm{CH}$ & $\mathrm{M}$ & $\mathrm{CH}$ & $\mathrm{M}$ & & \\
\hline$\overline{\mathrm{OPA} 02}$ & 100 & 100 & $6,2 \pm 1,4$ & \multicolumn{2}{|l|}{$5,8 \pm 1,0$} & 25,1 \\
\hline OPA07 & 100 & 100 & $7,1 \pm 0,4$ & $7,0 \pm 1,0$ & 19 & $32,1^{*}$ \\
\hline OPA20 & 76,9 & 100 & $7,6 \pm 0,5$ & $2,9 \pm 0,6^{*}$ & 10 & $30,5^{*}$ \\
\hline OPB01 & 75,0 & 100 & $5,5 \pm 0,5$ & $5,0 \pm 0,7$ & 12 & $23,4^{*}$ \\
\hline OPE07 & 93,3 & 100 & $10,1 \pm 0,7$ & $9,8 \pm 1,0$ & 21 & $50,8^{*}$ \\
\hline UBC450 & 100 & 100 & $5,1 \pm 1,2$ & $6,3 \pm 0,7$ & 11 & $27,8^{*}$ \\
\hline \multicolumn{7}{|c|}{$\begin{array}{l}\text { П р и м е ч а н и е. СН - станица Старо-Нижестеблиевская, } \mathrm{M}-\text { село Молдаванское. } \\
\text { * Различия между выборками статистически значимы }\left(t_{\text {факт. }} \geq t_{05}, \chi^{2} \text { факт. } \geq \chi^{2} 05\right) .\end{array}$} \\
\hline
\end{tabular}

Проведенный PCR-анализ показал, что низкая жизнеспособность стартовых популяций периллюса из села Молдаванское и его пищевые предпочтения, отличающие эту популяцию от других, обусловлены генетическими различиями.

В целом можно заключить, что с 2008 года, когда появились первые сообщения об акклиматизации хищного клопа P. bioculatus в Краснодарском крае $(28,32)$, энтомофаг, благодаря высокой миграционной способности и приобретению дополнительных трофических связей, сумел хорошо натурализоваться в этих новых условиях обитания. Получены аналогичные данные о быстром расселении хищного клопа на всей территории Молдавии $(36,37)$, а также в Турции $(39,41,42)$, Болгарии (43) и Сербии (44). Выявленное существенное влияние кормовой базы и энтомофагов на естественную численность этого клопа позволяет предположить, что аборигенные виды энтомофагов адаптировались к полезному адвентивному виду и способны снижать его численность. В некоторые годы это может нивелировать полезную деятельность природных популяций хищника, в связи с чем необходимо совершенствовать методы искусственного культивирования периллюса и создавать оптимальные условия для его активизации и воспроизводства в естественных условиях (отсутствие химических обработок и наличие кормовой базы).

Таким образом, в Краснодарском крае акклиматизировавшийся северо-американский хищный клоп Perillus bioculatus Fabr. стал эффективным естественным регулятором численности колорадского жука. Изучение биологических особенностей периллюса выявило существенное влияние на численность природных популяций хищника кормовой базы и аборигенных видов паразитоидов. Данные, полученные при скрещивании насекомых различных феноформ P. bioculatus, свидетельствуют о неменделевском характере наследования окраски щитка и различном проявлении этого признака в исследованных популяциях хищника. Детальный генетиче- 
ский анализ этого признака и его изменчивости в зависимости от условий внешней среды представляет научный интерес и имеет также практическое значение для оценки эффективности природных популяций энтомофага. Результаты оценки хищнической активности, жизнеспособности энтомофага и данные PCR-анализа различий в генетической структуре у изученных географических популяций согласуются.

\section{ЛИ И Е РАТ У РА}

1. Sablon L., Dickens J.C., Haubruge É., Verheggen F.J. Chemical ecology of the Colorado potato beetle, Leptinotarsa decemlineata (Say) (Coleoptera: Chrysomelidae), and Potential for Alternative Control Methods. Insects, 2013, 4: 31-54 (doi: 10.3390/insects4010031).

2. Lawrence S.D., Novak N.G., Ju C.J., Cooke J.E. Potato, Solanum tuberosum, defense against Colorado potato beetle, Leptinotarsa decemlineata (Say): microarray gene expression profiling of potato by Colorado potato beetle regurgitant treatment of wounded leaves. J. Chem. Ecol., 2008, 34(8): 1013-1025 (doi: 10.1007/s10886-008-9507-2).

3. Hare J.D. Ecology and management of the Colorado potato beetle. Annu. Rev. Entomol., 1990, 35: 81-100 (doi: 10.1146/annurev.en.35.010190.000501).

4. Hare J.D. Impact of defoliation by the Colorado potato beetle on potato yields. J. Econ. Entomol., 1980, 73: 369-373 (doi: 10.1093/jee/73.3.369).

5. Бабенко А.С., Штерншис М.В., Андреева И.В., Томилова О.Г., Коробов В.А. Энтомофаги в защите растений. Новосибирск, 2001.

6. Сухорученко Г.И., Долженко В.И., Новожилов К.В. Методы оценки действия инсектицидов на членистоногих. Вестник защиты растений, 2006, 1: 3-12.

7. Сумароков А.М. Восстановление биотического потенциала биогеоценозов при уменьшении пестицидных нагрузок. Донецк, 2009.

8. Танский В.И. Фитосанитарная устойчивость агробиоценозов. СПб, 2010.

9. Листопадова Е.С., Нефедова М.В., Агасьева И.С. Влияние биологических препаратов на комплекс энтомофагов. Международный научно-исследовательский журнал, 2014, 2(21-2): 10-11.

10. Долженко Т.В., Козлова Е.Г., Долженко О.В. Оценка действия инсектицидов на полезных членистоногих. Российская сельскохозяйственная наука, 2016, 2-3: 21-23.

11. Clausen C.P. Introduced parasites and predators of arthropod pests and Weed. World review. Washington, 1978.

12. Jasi I. On the life cycle of Perillus bioculatus (Heteroptera, Pentatomidae) in Slovakia. Acta Ent. Bohemoslovaca, 1975, 72(6): 38 -390.

13. Wegorek W.G., Pruszynski S. Stan badan nad introdukcija do Polsky wrogow naturalnych stronki ziemnisczanej (Leptinotarsa decemlineata Say). Post Nauk Roln., 1979, 5(26): 61-73.

14. Гусев Г.В. Энтомофаги колорадского жука. М., 1991.

15. Jermy T. The introduction of Perillus bioculatus into Europa to control the Colorado beetle. EPPO Bulletin, 1980, 10(4): 475-479 (doi: 10.1111/j.1365-2338.1980.tb01733.x).

16. Pruscynsky S., Wegorek W. Researchers on biology and introduction of Podisus maculiventris (Say) - new for Poland predator of the Colorado potato beetle (Leptinotarsa decemlineata Say). Mat. 22-j Ses. nauk; Inst. ochr. rosl. Poznan, 1981: 127-136.

17. De Clercq P. Spined soldier bug, Podisus maculiventris Say (Hemiptera: Pentatomidae: Asopinae). In: Encyclopedia of entomology /J.L. Capinera (ed.). Springer, Heidelberg, 2008, V. 4: 3508-3510.

18. Rabitsch W. True bugs (Hemiptera, Heteroptera). Chapter 9.1. Alien terrestrial arthropods of Europe /A. Roques, M. Kenis, D. Lees, C. Lopez-Vaamonde, W. Rabitsch, J.-Y. Rasplus, D. Roy (eds.). BioRisk, 2010, 4: 407-433 (doi: 10.3897/biorisk.4.44).

19. Rabitsch W. Alien true bugs of Europe (Insecta: Hemiptera: Heteroptera). Zootaxa, 2008, 1827: 1-44.

20. Wegorek P. Insecticide resistance management strategy for Colorado potato beetle (Leptinotarsa decemlineata Say) in Poland. Resistant Pest Management Newsletter, 2002, 11(2): 22-30.

21. Alyokhin A., Baker M., Mota-Sanchez D., Dively G., Grafius E. Colorado potato beetle resistance to insecticides. Am. J. Potato Res., 2008, 85(6): 395-413 (doi: 10.1007/s12230-0089052-0).

22. Alyokhin A. Colorado potato beetle management on potatoes: current challenges and future prospects. Fruit Vegetable and Cereal Science and Biotechnology, 2009, 3: 10-19.

23. Bishop B.A., Grafius E.J. Insecticide resistance in the Colorado potato beetle. In: Chrysomelidae biology /P.H.A. Jolivet, M.L. Cox (eds.). SBP Academic Publishing, Amsterdam, The Netherlands, 1996, V. 1: 355-377.

24. Grafius E.J. Is local selection followed by dispersal a mechanism for rapid development of multiple insecticide resistance in the Colorado potato beetle? American Entomologist, 1995, 41(2): 
104-109 (doi: 10.1093/ae/41.2.104).

25. Alyokhin A., Dively G., Patterson M., Castaldo C., Rogers D., Mahoney M., Wollam J. Resistance and cross-resistance to imidacloprid and thiamethoxam in the Colorado potato beetle Leptinotarsa decemlineata. Pest Manag Sci. 2007, 63(1): 32-41 (doi: 10.1002/ps. 1305).

26. Mota-Sanchez D., Hollingworth R.M., Grafius E.J., Moyer D.D. Resistance and crossresistance to neonicotinoid insecticides and spinosad in the Colorado potato beetle, Leptinotarsa decemlineata (Say) (Coleoptera: Chrysomelidae). Pest Manag. Sci., 2006, 62(1): 30-37 (doi: 10.1002/ps.1120).

27. Scott I.M., Tolman J.H., MacArthur D.C. Insecticide resistance and cross-resistance development in Colorado potato beetle Leptinotarsa decemlineata Say (Coleoptera: Chrysomelidae) populations in Canada 2008-2011. Pest Manag. Sci.., 2015, 71(5): 712-721 (doi: 10.1002/ps.3833).

28. Нейморовец В.В. Хищный клоп периллюс осваивает юг России. Природа, 2016, 2: 43-48.

29. Агасьева И.С., Нефедова М.В. Изучение возможности хранения хищных клопов подсемейства Asopinae, используемых для защиты пасленовых культур от колорадского жука. Евразийский союз ученых (ЕСУ), 2015, 6(5): 90-93.

30. Киль В.И., Исмаилов В.Я., Агасьева И.С. Особенности биологии хищного клопа Perillus bioculatus F. и изучение его филогении методом ПЦР. Российская сельскохозяйственная наука, 2012, 3: 30-33.

31. Агасьева И.С., Исмаилов В.Я., Нефедова М.В. Использование химических и биологических средств для подавления численности колорадского жука. Труды Кубанского государственного аграрного университета, 2014, 3(48): 27-30.

32. Агасьева И.С., Исмаилов В.Я., Нефедова М.В., Федоренко Е.В. Видовой состав и биорегуляторная активность энтомофагов в системе управления численностью вредителей картофеля (Solanum tuberosum L.). Сельскохозяйственная биология, 2016, 51(3): 401-410 (doi: 10.15389/agrobiology.2016.3.401 rus).

33. Воронин К.Е., Пукинская Г.А., Исак И.В., Асекян Б.П., Воронина Э.Г., Бондаренко Н.В., Ряховский В.В., Дядечко Н.П., Яснош В.А. Методические указания по использованию критериев эффективности природных популяций энтомофагов и энтомопатогенов /Под ред. К.В. Новожилова. М., 1991.

34. Yeh F.C., Yang R.C., Boyle T.B.J., Ye Z.H., Mao J.X. POPGENE, the user-friendly shareware for population genetic analysis. Computer program and documentation. Molecular Biology and Biotechnology Centre, University of Alberta, Edmonton, 1997.

35. Доспехов Б.А. Методика полевого опыта. М., 1985.

36. Derjanschi V., Elisoveţcaia D., Calestru L. Ploşniţa Perillus bioculatus F. (Heteroptera, Pentatomidae) - prăd torul principal al gândacului de Colorado. Akademos, 2013, 4(31): 90-93.

37. Derjanschi V., Elisovețcaia D. Predatory shield bug Perillus bioculatus F. (Hemiptera, Pentatomidae) in the Republic of Moldova: acclimatization or natural colonization? Proc. Int. Conf. of Zooloists «Actual problems of protection and sustainable use of the animal world diversity». Chisinau, 2013, Iss. 8: 124-125.

38. Шагов Е.М.. Влияние температуры на хищного клопа Perillus bioculatus Fabr. (Hemiptera: Pentatomidae). Зоологический журнал, 1968, XLVII(4): 563-570.

39. Fent M., Aktaç N. Die Verbreitung des Perillus bioculatus (Fab.) (Heteroptera: Pentatomidae: Asopinae) im türkischen Teil Thrakiens. Heteropteron, 2007, 25: 7-10.

40. Coudron T.A., Kim Y. Life history and cost analysis for continuous rearing of Perillus bioculatus (Heteroptera: Pentatomidae) on a zoophytogenous artificial diet. Biological and Microbial Control. J. Econ. Entomol., 2004, 3: 807-812 (doi: 10.1093/jee/97.3.807).

41. Kivan M. Some observations on Perillus bioculatus (F.) (Heteroptera: Pentatomidae) a new record for the entomofauna of Turkey. Türkish Journal of Entomology, 2004, 28(2): 95-98.

42. Onder F., Karsavuran Y., Tezcan S., Fent M. Heteroptera (Insecta) catalogue of Turkey. Meta Basým Matbaacýlýk Hizmetleri, Ýzmir, 2006.

43. Simov N., Langourov M., Grozeva S., Gradinarov D. New and interesting records of alien and native true bugs (Hemiptera: Heteroptera) from Bulgaria. Acta zoologica bulgarica, 2012, 3(64): 241-252.

44. Proti L.J., Živi N. Perillus bioculatus (Fabricius) (Heteroptera: Pentatomidae) in Serbia. Acta entomologica serbica, 2012, 17(1/2): 23-28.

1ФГБНУ Всероссийский НИИ биологической зашиты растений,

350039 Россия, г. Краснодар, п/о 39,

e-mail: vlyaism@yandex.ru, agasieva5@yandex.ru,vlkil@inbox.ru,

ms.fedor1960@mail.ru, dollkaSneba@yandex.ru, katrina7283@yandex.ru $\bowtie$;

2 ФГБОУ ВО Кубанский государственный университет,

350040 Россия, г. Краснодар, ул. Ставропольская, 149,

e-mail: vlkil@inbox.ru $₫$

Поступила в редакцию

20 марта 2018 года 


\title{
BIOLOGICAL CHARACTERIZATION, PHENOTYPIC AND GENOTYPIC STRUCTURE OF PREDATORY STINKBUG Perillus bioculatus Fabr. (Heteroptera, Pentatomidae) POPULATION IN KRASNODAR REGION
}

\author{
V.Ya. Ismailov', I.S. Agas'eva', V.I. Kil', E.V. Fedorenko', M.V. Nefedova', \\ E.N. Besedina ${ }^{1}$
}

${ }^{1}$ All-Russian Research Institute of Biological Plant Protection, PO box 39, Krasnodar, 350039 Russia, e-mail vlyaism@yandex.ru, agasieva5@yandex.ru, vlkil@inbox.ru, ms.fedor1960@mail.ru, dollkaSneba@yandex.ru, katrina7283@yandex.ru ( $\bowtie$ corresponding author);

${ }^{2}$ Kuban State University, 149, ul. Stavropolskaya, Krasnodar, 350040 Russia, e-mail vlkil@inbox.ru ( $₫$ corresponding author)

ORCID:

Ismailov V.Ya. orcid.org/0000-0002-6713-0059

Agas'eva I.S. orcid.org/0000-0002-1216-1106

Kil V.I. orcid.org/0000-0002-3762-9019

Fedorenko E.V. orcid.org/0000-0003-4411-626X

The authors declare no conflict of interests

Nefedova M.V. orcid.org/0000-0001-5390-233X

Acknowledgements:

The studies were performed according to the State Task No. 075-00376-19-00 of the Ministry of Science and Higher Education of the Russian Federation within the framework of scientific research work on the subject No 0686-2019-0009

Received March 20, 2018

doi: 10.15389/agrobiology.2019.1.110eng

\section{Abstract}

Perillus bioculatus Fabr. (1775) is a predatory bug in the family Pentatomidae, a prospective North American entomophage of the Colorado potato beetle. Earlier, Colorado potato beetle eggs were deemed the most preferable for the predator feeding and the main obstacle for perillus acclimatization on new territories. However, in monitoring perillus populations that have acclimatized in several areas of Krasnodar region for the last decade, we revealed the predators' feeding on ragweed leaf beetle (Zygogramma suturalis Fabr.) larvae and ragweed cutworm Tarachidia candefacta Hübn. (Noctuidae: Lepidoptera) caterpillars and also on all growth stages of Colorado potato beetle and other insects. In Krasnodar Krai perillus can give annually three generations and is present in three phenoforms, with red-black, orange-black and white-black scutellum. The abundance of P. bioculatus is influenced by feeding conditions and by other entomophages, e.g. egg-eaters of genus Trissolcus (Hymenoptera: Scelionidae) and tachina flies (Diptera: Tachinidae). Analysis of scutellum color inheritance in seven different crosses, including reciprocal ones, between red, orange (or yellow) and white parents showed that the $F_{1}$ and $F_{2}$ progeny from all combinations, including white individuals crossed with each other, have only red and orange shield (1:1). PCR analysis of $P$. bioculatus bugs in $\mathrm{F}_{2}$ from crossing insects of different phenoforms revealed that the bugs with the same phenoform in $\mathrm{F}_{2}$ are genetically different from each other for the frequency of certain RAPD markers. These data indicate non-Mendelian inheritance of scutellum coloration trait in perillus that additionally attract attention to the point. RAPD (random amplification of polymorphic DNA)- and ISSR(inter simple sequence repeat)-PCR analysis detected intra- and inter-population variation of the predatory bugs molecular genetic structure from different zones of the Krasnodar Krai. PCR analysis with almost all used specific primers revealed statistically significant differences $(p=0.05)$ in molecular genetic structure and DNA polymorphism for the populations studied. Geographic populations from the village of Staro-Nizhesteblievskaya and the city of Krasnodar (Krasnodar Krai) were genetically close while there genetic identities with the Moldavian village (Crimean region, Krasnodar Krai) population were low. This comports with their geographical location and indicates geographic variability of $P$. bioculatus populations' genetic structure. The researches executed by us confirm plasticity of this species and prospects for its further acclimatization within Colorado potato beetle area.

Keywords: predatory bugs, Perillus bioculatus Fabr., adventive species, acclimatization, PCR analysis, molecular genetic similarity, Colorado beetle, entomophages, biocontrol.

\section{Научные собрания \\ MOSCOW CONFERENCE ON COMPUTATIONAL MOLECULAR BIOLOGY (MCCMB)}

(July 27-30, 2019, Moscow, Russia)

Moscow Conference on Computational Molecular Biology (MCCMB) is a biennial forum in various up-to-date areas of computational biology. It traditionally takes place in Lomonosov Moscow State University, but despite its "local" title both Russian and international scientists participate the conference. The working language of the conference is English.

Information: http://vigg.ru/nauchnaja-dejatelnost/konferencii-i-shkoly/ 